\title{
Upper Jaw Tooth
}

National Cancer Institute

\section{Source}

National Cancer Institute. Upper Jaw Tooth. NCI Thesaurus. Code C49792.

Any of the teeth located in the upper jaw. 